\title{
Establishment and biological analysis of the EC109/CDDP multidrug-resistant esophageal squamous cell carcinoma cell line
}

\author{
JING WEN, BIN ZHENG, YI HU, XU ZHANG, HONG YANG, KONG-JIA LUO, \\ XING ZHANG, YONG-FENG LI and JIAN-HUA FU \\ Department of Thoracic Oncology, Cancer Center, Sun Yat-Sen University, State Key Laboratory of \\ Oncology in Southern China, 651 Dongfeng Rd, East, Guangzhou 510060, P.R. China
}

Received December 19, 2008; Accepted February 9, 2009

DOI: 10.3892/or_00000407

\begin{abstract}
The aim of this study was to establish a stable, drug-resistant esophageal squamous cell carcinoma (ESCC) cell line. The human ESCC cell line EC109 was exposed to cisplatin (CDDP) by pulse treatment to select for the drugresistant subline, EC109/CDDP cells. The MTT assay was used to test the drug resistance of EC109 and EC109/CDDP cells. In addition, cellular morphological changes were observed using microscopy and the growth curves of the two cell lines were drawn to calculate the doubling time. Furthermore, cell cycle distribution was analyzed by flow cytometry. Finally, RT-PCR was performed to determine the mRNA expression levels of drug-resistant-related genes, multidrug resistance 1 (MDR1), multidrug resistanceassociated protein 1 (MRP1), ATP-binding cassette, subfamily $\mathrm{G}$, member 2 (ABCG2), lung resistance protein (LRP), and glutathione S-transferase (GST)-pi in both cell lines. EC109/CDDP cells exhibited increased resistance to CDDP, carboplatin, 5-fluorouracil, taxol, navelbine, irinotecan and etoposide, and changes in morphology, doubling time, and cell cycle distribution were detected as compared with EC109 cells. Although there was no significant difference in MRP1, ABCG2, LRP, and GST-pi expression, MDR1 expression in EC109/CDDP cells was lower than that of EC109 cells. EC109/CDDP cells are a stable, multidrug-resistant ESCC cell line and could serve as an important tool for further research concerning ESCC drug resistance.
\end{abstract}

\section{Introduction}

Esophageal cancer (EC) is one of the most common malignancies in the world. It was estimated that $>300,000$ people die of it every year, ranking as the sixth leading cause of cancer

Correspondence to: Professor Jian-hua Fu, Department of Thoracic Oncology, Cancer Center, Sun Yat-Sen University, State Key Laboratory of Oncology in Southern China, 651 Dongfeng Rd, East, Guangzhou 510060, P.R. China

E-mail: fjh@medmail.com.cn

Key words: esophageal squamous cell carcinoma, cell line, multidrug resistance death worldwide (1). Most esophageal cancers in China are squamous cell carcinomas (SCCs), which is different from the most prevalent esophageal cancers, adenocarcinomas, in Western countries, leading to distinct etiologies, therapeutics and prognosis (2). Despite advances in surgical therapy for esophageal squamous cell carcinoma (ESCC), the overall prognosis of patients has not improved markedly during the past few decades due to the fact that most patients have locally-advanced or disseminated diseases at diagnosis (3). For these unresectable diseases, chemotherapy alone (stage IV) or in combination with other local treatment modalities (stages II and III) would be an optimal choice. However, the success of chemotherapy depends on the sensitivity of the tumor to the antineoplastic agents. ESCC cells often acquire resistance to drugs and even develop multiple drug resistance, which results in treatment failure. Although extensive study has been done on drug resistance, there are still some issues that cannot be explained by the well-characterized mechanisms of drug resistance.

Drug-resistant cell lines, selected by exposure to antitumor agents, have been valuable tools for the illumination of the factors underlying drug resistance. For example, Juliano and Ling discovered P-glycoprotein via selection of resistant Chinese hamster ovary cells to colchicines (4). However, in vitro culture of drug-resistant cell lines may not always reflect or even may be contradictory to what is occurring in vivo, some of which is most likely due to the distinct patterns of drug use between laboratory research and the clinical practice. Until now, the most common methods of establishing drug-resistant cell lines include i) increasing continuous administration, ii) low-dosage intermittent incremental inducement and iii) pulse treatment. The two former methods might be different from clinical chemotherapy, in which a pulse protocol with a certain interval is commonly adopted, arousing a failure to link the laboratory and the clinic (5).

Few mechanisms of drug resistance and markers of resistance were first detected in ESCC. Most previous studies of drug resistance have been focused on other types of cancer. For example, the multidrug resistance-associated protein 1 (MRP1, or ABCC1) (6) and lung resistance protein (LRP, or MVP) (7) were initially discovered in drug-resistant lung cancer cell lines, and the ATP-binding cassette, sub-family G, member 2 protein (ABCG2, also known as BCRP, MXR, or ABC-P) (8) was first detected in a multidrug-resistant breast 
cancer cell line. Whether ESCC cells share common drug resistance mechanisms with other cancers or possess their own distinct characteristics is still in doubt. Hence, it is of great necessity to establish an antitumor drug-resistant ESCC cell line in vitro by imitating the clinical chemotherapy pattern in order to facilitate further research that may contribute to solving some common clinical problems.

In the present study, we established a drug-resistant cell line EC109/CDDP cells by pulse treatment of the most widely-used antitumor drug, cisplatin (CDDP) to the ESCC cell line, EC109 cells. In addition, the biological characteristics and mRNA expression of some drug resistance-related genes of the resistant and parental cell lines were analyzed. This cell line and further characterization will lay a foundation for further research on the mechanisms by which ESCC becomes drug-resistant.

\section{Materials and methods}

Drugs. CDDP was purchased from Mayne Pharma Pty. Ltd. (Victoria, Australia) and stored at a concentration of $1 \mathrm{mg} / \mathrm{ml}$ at room temperature. Carboplatin and taxol were obtained from Bristol-Myers Squibb (NY, USA) and stored at a concentration of $10 \mathrm{mg} / \mathrm{ml}$ and $6 \mathrm{mg} / \mathrm{ml}$ at room temperature, respectively. Navelbine was purchased from Laboratories Pierre Fabre (Castres Cedex, France) and stored at the concentration of $10 \mathrm{mg} / \mathrm{ml}$ at $4^{\circ} \mathrm{C}$. Irinotecan was purchased from Pfizer Pharmaceuticals Ltd. (NY, USA) and stored at a concentration of $20 \mathrm{mg} / \mathrm{ml}$ at room temperature. 5Fluorouracil (5-FU) was purchased from Nantong Jinghua Pharmaceutical Co. (Jiangsu, China) and stored at the concentration of $25 \mathrm{mg} / \mathrm{ml}$ at room temperature. Etoposide and cyclophosphamide both were purchased from Hengrui Medicine Company (Jiangsu, China) and stored at the concentration of $20 \mathrm{mg} / \mathrm{ml}$ diluted in $0.9 \% \mathrm{NaCl}$ at room temperature. Pirarubicin hydrochloride was purchased from Hisun Pharmaceutical Co. (Zhejiang, China) and stored at the concentration of $1 \mathrm{mg} / \mathrm{ml}$ diluted in $0.9 \% \mathrm{NaCl}$ at $4^{\circ} \mathrm{C}$.

Cell culture. The EC109/CDDP cell line was generated by exposing EC109 cells to CDDP at pulse treatment of $25 \mu \mathrm{M}$ for $2 \mathrm{~h}$, and then the drug-containing medium was replaced by drug-free medium. Another treatment was not administered until the cells were in exponential growth phase. The cells were induced 6 times in $25 \mu \mathrm{M}$ CDDP. EC109 and EC109/CDDP cells were cultured in the Dulbecco's modified Eagle's medium (DMEM) (Invitrogen, NY, USA) supplemented with 10\% fetal bovine serum, $100 \mathrm{U} / \mathrm{ml}$ penicillin (Tianxin, Guangzhou, China) and $100 \mathrm{U} / \mathrm{ml}$ streptomycin (Merro, Dalian, China) in a humidified incubator containing $5 \% \mathrm{CO}_{2}$ at $37^{\circ} \mathrm{C}$. No experiments were performed until all the cells had been maintained in drug-free medium for 1 month.

MTT assay. The cytotoxicities of CDDP, carboplatin, 5-FU, taxol, navelbine, irinotecan, etoposide, cyclophosphamide and pirarubicin were determined using the MTT assay. Monodispersed cells in the exponential growth phase following trypsinization were plated in $200 \mu 1$ of medium/well in 96-well plates. Following overnight incubation, the medium was removed and replaced by various concentrations of the drugs mentioned above. Eight different concentrations for each drug were analyzed and three wells were used for each determination. Medium without drug was added to the control and blank wells. After a $48 \mathrm{~h}$ incubation, $100 \mu \mathrm{l}$ of 3-[4,5dimethyl-2-thiazol]-2,5-diphenyl-2H tetrazolium bromide (MTT, Amresco, MA, USA) solution at the final concentration of $0.5 \mathrm{mg} / \mathrm{ml}$ was added to the wells with the exception of the blank wells for $4 \mathrm{~h}$ at $37^{\circ} \mathrm{C}$. Then MTT solution was removed and the insoluble formazan crystals were dissolved in $100 \mu 1$ of dimethylsulfoxide (DMSO, Sigma-Aldrich, MO, USA). The absorbance was measured at 570 and $655 \mathrm{~nm}$ using a SpectraMax M5 (Molecular Devices, CA, USA). All experiments were performed at least three times. Resistance indices (RIs) were determined by the ratio of the inhibitory concentration $50 \%\left(\mathrm{IC}_{50}\right)$ values of EC109/CDDP to EC109 cells.

Analysis of morphological changes. Exponentially growing EC109 and EC109/CDDP cells were transferred to 35-mm dishes (BD Falcon, NJ, USA) and allowed to adhere in $5 \%$ $\mathrm{CO}_{2}$ at $37^{\circ} \mathrm{C}$ for at least $24 \mathrm{~h}$. The cells were then observed under the light microscopy using an Olympus CKX41 (Tokyo, Japan) and photographed by a Cannon A640 (Tokyo, Japan).

Growth curves and the doubling time $\left(T_{d}\right)$. Single-cell suspensions were prepared from the cells in exponential growth phase. Aliquots containing 20,000 cells were seeded in 60-mm dishes (BD Falcon) with $5 \mathrm{ml}$ of medium. Three wells were used for each determination, and after staining with $0.4 \%$ trypan blue (Sigma-Aldrich), three cell counts for each well from each cell line were made every $24 \mathrm{~h}$ for 10 days. The doubling time $\left(\mathrm{T}_{\mathrm{d}}\right)$ of each cell line was counted according to the formula $\mathrm{T}_{\mathrm{d}}=\mathrm{Tx} \lg 2 /\left(\lg \mathrm{N}_{2}-\lg \mathrm{N}_{1}\right) ; \mathrm{N}_{1}$ is the cell number at the beginning; and $\mathrm{N}_{2}$ is the cell number at the end, usually the end of exponential phase. $T$ is the time from $\mathrm{N}_{1}$ to $\mathrm{N}_{2}$.

Cell cycle analysis by flow cytometry. Monodispersed cells $\left(1 \times 10^{6}\right)$ were harvested during the exponential growth phase following trypsinization. The cells were washed with PBS and fixed in $70 \%$ ethanol at $4^{\circ} \mathrm{C}$ overnight. The fixed cells were washed and resuspended in $1 \mathrm{ml}$ PBS containing $50 \mu \mathrm{g} / \mathrm{ml}$ propidine iodide (Sigma-Aldrich) and $0.1 \mathrm{mg} / \mathrm{ml} \mathrm{RNaseA}$ (Sigma-Aldrich). Then, the samples were incubated at $37^{\circ} \mathrm{C}$ for $30 \mathrm{~min}$ in the darkness and analyzed on a FACSCalibur (BD Company, Franklin Lakes, NJ, USA). At least 10,000 events were counted for each sample and triplicate experiments were conducted for each cell line.

Semi-quantitative RT-PCR. The mRNA expression of multidrug resistance-related genes, ATP-binding cassette, sub-family B, member 1 (MDR1), ATP-binding cassette, sub-family $\mathrm{C}$, member 1 (MRP1), ATP-binding cassette, sub-family $\mathrm{G}$, member2 (ABCG2), lung resistance protein (LRP), and glutathione S-transferase pi (GST-pi), were determined using semi-quantitative RT-PCR. Total RNA was isolated from EC109 and EC109/CDDP cells using TRIzol reagent (Invitrogen, CA, USA) according to the manufacturer's instructions. RNA was quantified spectrophotometrically by Nucleic Acid/Protein Analyzer DU 800 (Beckman Coulter, 
Table I. Primers used for RT-PCR analysis.

\begin{tabular}{|c|c|c|c|c|}
\hline Gene & Primers $\left(5^{\prime} \rightarrow 3^{\prime}\right)$ & $\begin{array}{l}\text { Gene bank } \\
\text { accession no. }\end{array}$ & $\begin{array}{l}\text { Annealing } \\
\text { temperature }\left({ }^{\circ} \mathrm{C}\right)\end{array}$ & Size (bp) \\
\hline MDR1 (9) & & NM_000927.3 & 60 & 237 \\
\hline Sense & $\begin{array}{l}\text { GTGCTGGTTGCTGCTTACAT } \\
791-810\end{array}$ & & & \\
\hline Anti-sense & $\begin{array}{l}\text { CCCAGTGAAAAATGTTGCCA } \\
1027-1008\end{array}$ & & & \\
\hline MRP1(10) & & NM_019898.2 & 53 & 562 \\
\hline Sense & $\begin{array}{l}\text { CATCAACATCGCCAAGA } \\
4072-4088\end{array}$ & & & \\
\hline Anti-sense & $\begin{array}{l}\text { GTTCTGACCAGATATGC } \\
4633-4616\end{array}$ & & & \\
\hline ABCG2 (11) & & NM_004827.2 & 60 & 342 \\
\hline Sense & $\begin{array}{l}\text { GGCCTCAGGAAGACTTATGT } \\
1270-1289\end{array}$ & & & \\
\hline Anti-sense & $\begin{array}{l}\text { AAGGAGGTGGTGTAGCTGAT } \\
1611-1592\end{array}$ & & & \\
\hline LRP (12) & & NM_017458.2 & 54 & 240 \\
\hline Sense & $\begin{array}{l}\text { GTCTTCGGGCCTGAGCTGGTGTCG } \\
1561-1584\end{array}$ & & & \\
\hline Anti-sense & $\begin{array}{l}\text { CTTGGCCGTCTCTTGGGGGTCCTT } \\
1800-1777\end{array}$ & & & \\
\hline GST-pi (13) & & NM_000852.2 & 60 & 245 \\
\hline Sense & $\begin{array}{l}\text { GGCTCACTCAAAGCCTCCTG } \\
153-172\end{array}$ & & & \\
\hline Anti-sense & $\begin{array}{l}\text { AGTGCCTTCACATAGTCATC } \\
397-378\end{array}$ & & & \\
\hline B-actin & & NM_001101.2 & 55 & 619 \\
\hline Sense & $\begin{array}{l}\text { CGGGACCTGACTGACTACCTCATCAAGA } \\
620-647\end{array}$ & & & \\
\hline Anti-sense & $\begin{array}{l}\text { TCAAGAAAGGGTGTAACGCAACTA } \\
1238-1215\end{array}$ & & & \\
\hline
\end{tabular}

CA, USA) and its quality was checked by electrophoresis through denaturing agarose gels. Only samples that were not degraded (i.e., ones that showed clear $18 \mathrm{~S}$ and $28 \mathrm{~S}$ bands under ultraviolet light) were used for semi-quantitative RTPCR. Total RNA was reverse-transcribed using the first-strand cDNA synthesis kit (Toyobo, Osaka, Japan). Specifically, $\sim 1 \mu \mathrm{g}$ RNA added with $1 \mu \mathrm{l}$ random primer $(25 \mathrm{mM})$ was denatured at $70^{\circ} \mathrm{C}$ for 10 min and then quickly chilled on ice. To synthesize cDNA, a reaction mixture was added to the denatured RNA such that the final $20 \mu 1$ reaction volume contained $4 \mu \mathrm{l}$ 5X RT buffer (containing $25 \mathrm{mM} \mathrm{Mg}^{2+}$ ), $1 \mu \mathrm{l}$ RNase inhibitor $(10 \mathrm{U} / \mu \mathrm{l}), 1 \mu \mathrm{l}$ Moloney murine leukemia virus reverse transcriptase $(100 \mathrm{U} / \mu \mathrm{l})$ and $1 \mu \mathrm{ldNTP}$ mixture (each $10 \mathrm{mM}$ ). The reaction was incubated at $37^{\circ} \mathrm{C}$ overnight followed by $99^{\circ} \mathrm{C}$ for $5 \mathrm{~min}$ and $4^{\circ} \mathrm{C}$ for $5 \mathrm{~min}$. Then cDNA $(1 \mu \mathrm{l})$ was amplified by PCR using $0.1 \mu \mathrm{l}$ rTaq DNA polymerase (5 U/ $\mu \mathrm{l}$ ) (Toyobo), $2 \mu 1$ 10X PCR buffer [containing $500 \mathrm{mM} \mathrm{KCl}, 100 \mathrm{mM}$ Tris- $\mathrm{HCl}(\mathrm{pH}$ 8.3) and 15
$\left.\mathrm{mM} \mathrm{Mg}{ }^{2+}\right], 4 \mu \mathrm{l}$ dNTP mixture (each $1 \mathrm{mM}$ ) and $0.5 \mu 1$ each of the primers ( $10 \mathrm{mM}$ for each primer) with the total volume of $20 \mu \mathrm{l}$. As shown in Table I, the primer sequences, the length of products, and PCR reaction conditions are listed, and the primers were synthesized according to previous studies (9-13). B-actin was used as an internal control. PCR products (10 $\mu 1$ ) were mixed with $2 \mu 1$ DNA loading buffer containing $0.1 \%$ SYBR-Green I and separated on $1.5 \%$ agarose gels. Gels were visualized by Gel Doc (Bio-Rad, CA, USA) and analyzed by Quantity One V4.62 (Bio-Rad). The level of specific mRNA was measured and expressed as a ratio of the optical density band of each gene to that of the housekeeping gene, $\beta$-actin.

Statistical analysis. Data are expressed as mean \pm standard deviation (SD) of at least three repeated experiments. Data analysis was carried out utilizing the SPSS 16.0 statistical software package (SPSS, IL, USA). Continuous variables were 

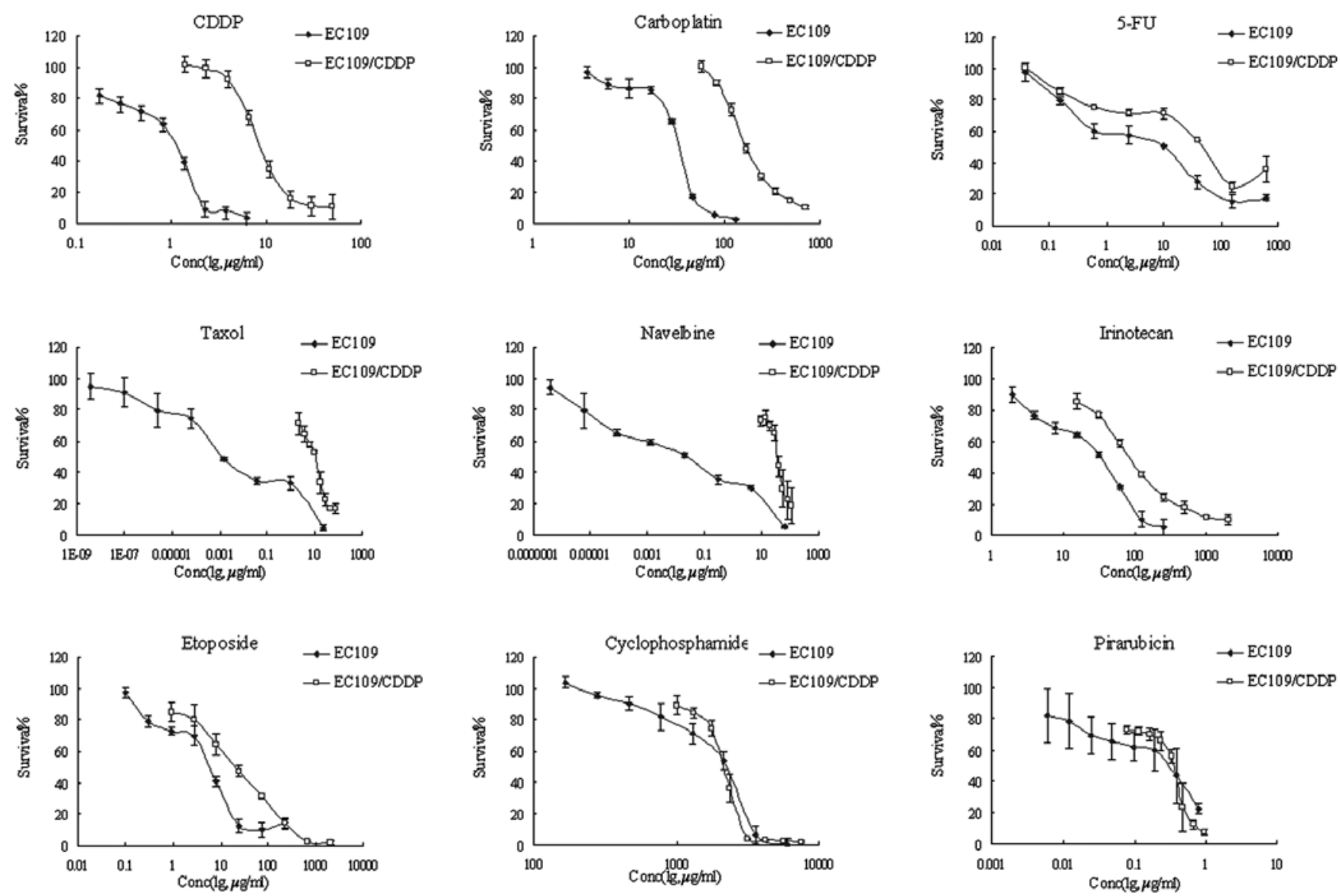

Figure 1. EC109 and EC109/CDDP cell survival curves. Survival curves were determined using the MTT assay for EC109 cells and its derivative-resistant subline, EC109/CDDP.

Table II. Drug sensitivity of EC109 and EC109/CDDP.

\begin{tabular}{|c|c|c|c|c|}
\hline \multirow[b]{2}{*}{ Drugs } & \multicolumn{2}{|c|}{$\mathrm{IC}_{50}($ mean $\pm \mathrm{SD}, \mu \mathrm{g} / \mathrm{ml})$} & \multirow[b]{2}{*}{ RI } & \multirow[b]{2}{*}{ P-value } \\
\hline & EC109 & EC109/CDDP & & \\
\hline Cisplatin & $1.018 \pm 0.02615$ & $8.829 \pm 0.2390$ & 8.668 & $<0.001$ \\
\hline Carboplatin & $30.41 \pm 0.8430$ & $169.3 \pm 3.482$ & 5.568 & $<0.001$ \\
\hline 5- Fluororacil & $10.22 \pm 0.3823$ & $46.25 \pm 1.883$ & 4.526 & $<0.001$ \\
\hline Taxol & $0.002357 \pm 0.0008551$ & $10.87 \pm 0.4329$ & 4609 & 0.001 \\
\hline Navelbine & $0.01396 \pm 0.0003433$ & $38.21 \pm 5.126$ & 2737 & $<0.001$ \\
\hline Irinotecan & $29.51 \pm 0.5956$ & $87.03 \pm 1.418$ & 2.950 & $<0.001$ \\
\hline Etoposide & $5.914 \pm 0.09332$ & $21.13 \pm 3.723$ & 3.573 & 0.019 \\
\hline Cyclophosphamide & $1876 \pm 77.30$ & $2110 \pm 81.89$ & 1.125 & 0.023 \\
\hline Pirarubicin & $0.3550 \pm 0.02577$ & $0.3599 \pm 0.03015$ & 1.014 & 0.812 \\
\hline
\end{tabular}

analyzed using Student's t-test. $\mathrm{P}<0.05$ was considered statistically significant and the reported P-values are twosided.

\section{Results}

Establishment and phenotype of the resistant subline, EC109/CDDP cells. The establishment of CDDP-resistant subline, EC109/CDDP cells, was completed over a period of 12 months. EC109/CDDP cells were then cultured in drugfree medium for at least 4 months. The resistance to CDDP was stable by examining the $\mathrm{IC}_{50}$ at monthly intervals during the period of culturing in drug-free medium. The drug sensitivity data of EC109 and EC109/CDDP cells to various kinds of drugs are shown in Table II and Fig. 1. EC109/ CDDP cells exhibited cross-resistance to several other drugs, to which they were not exposed, indicating it was a multidrugresistant cell line. 

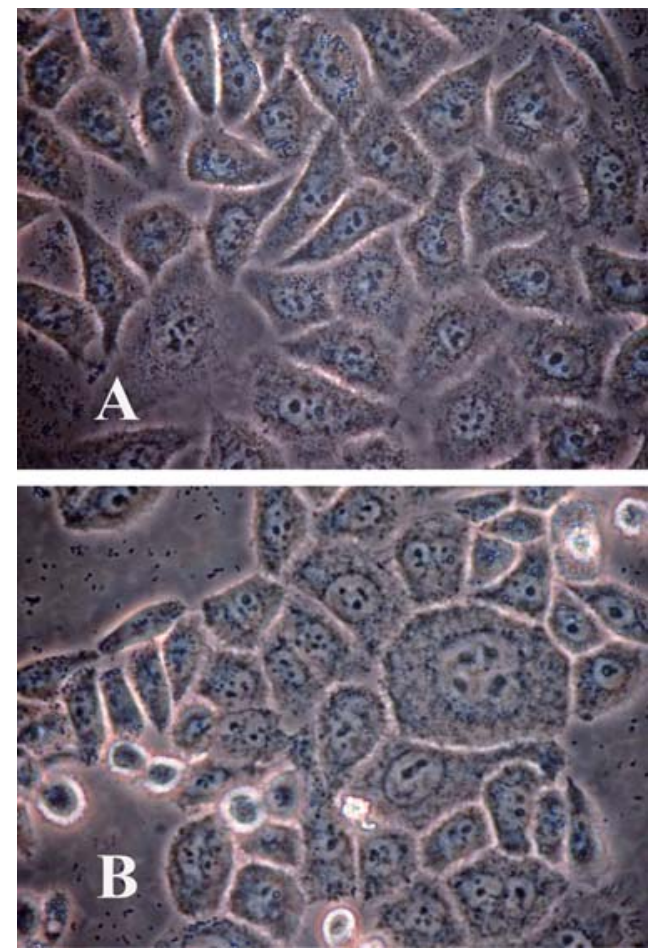

Figure 2. Morphology of EC109 (A) and EC109/CDDP (B) cells in exponential phase. Morphological characteristics were determined using an inverted microscope at original magnification of x400. EC109 cells were relatively uniform in size and shape as polygons, while EC109/CDDP cells showed irregular shape and size, with some giant and some small cells.

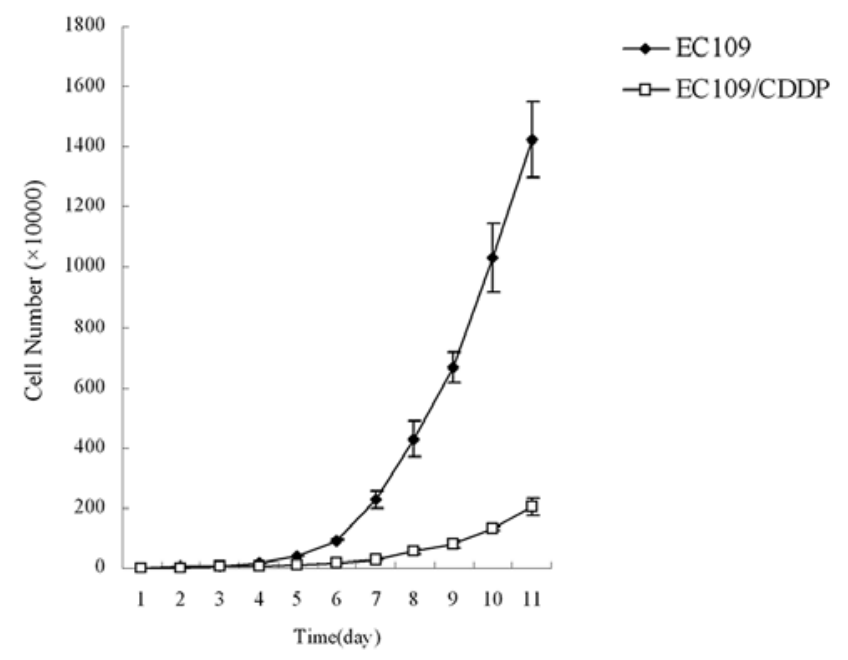

Figure 3. Growth curves of EC109 and EC109/CDDP cells.

Morphological changes of EC109/CDDP cells compared with EC109 cells. Both EC109 and EC109/CDDP cells grew adherent to the disk and showed epithelial-like shape as polygon. EC109 cells had relatively uniform cell size and shape. However, EC109/CDDP showed irregular shape and varied in size; both giant as well as small cells were detected (Fig. 2).

Cell growth curves and doubling time $\left(T_{d}\right)$. EC109 cells were in the logarithmic growth phase on the first day after seeding. However, there were fewer EC109/CDDP cells after seeding,
Table III. Cell cycle distribution of EC109 and EC109/CDDP cells.

\begin{tabular}{|c|c|c|c|}
\hline \multirow[b]{2}{*}{ Cell lines } & \multicolumn{3}{|c|}{$\begin{array}{l}\text { Percentage of each cell cycle } \\
\text { phase }(\text { mean } \pm \mathrm{SD}, \%)\end{array}$} \\
\hline & $\mathrm{G}_{0} / \mathrm{G}_{1}$ & $\mathrm{~S}$ & $\mathrm{G}_{2} / \mathrm{M}$ \\
\hline EC109 & $52.84 \pm 1.94$ & $33.78 \pm 1.60$ & $13.37 \pm 1.73$ \\
\hline EC109/CDDP & $57.94 \pm 3.73^{a}$ & $28.86 \pm 3.29^{a}$ & $13.20 \pm 2.61$ \\
\hline
\end{tabular}

${ }^{\mathrm{a}} \mathrm{P}<0.05$ vs. EC109 cells.

probably due to the lower cell adherence. According to the cell growth curves (Fig. 3), the $\mathrm{T}_{\mathrm{d}}$ of EC109 and EC109/CDDP cells was $20.74 \pm 1.31 \mathrm{~h}$ and $36.12 \pm 0.99 \mathrm{~h}$, respectively, which was significantly different $(\mathrm{P}<0.001)$.

Cell cycle distribution and DNA content. Cell cycle distribution and DNA content analyzed by flow cytometry are shown in Table III and Fig. 4, respectively. There were more EC109/ CDDP cells in $\mathrm{G}_{0} / \mathrm{G}_{1}$ phase and less in $\mathrm{S}$ phase as compared to EC109 cells ( $\mathrm{P}=0.040$ and 0.026 , respectively). There was no significant difference between the two cells in $G_{2} / M$ phase $(\mathrm{P}=0.912)$.

Expression of drug resistance-related genes. Gene expression analysis of MDR1, MRP1, LRP, ABCG2, and GST-pi is shown in Fig. 5A. After normalizing the mRNA expression level of each gene relative to that of $B$-actin, the expression levels of MDR1, MRP1, ABCG2, LRP and GST-pi in EC109 cells were $0.908 \pm 0.110,0.984 \pm 0.104,1.065 \pm 0.034$, $0.973 \pm 0.0376$ and $1.12 \pm 0.124$, respectively and in EC109/ CDDP cells were $0.307 \pm 0.0321,0.952 \pm 0.143,1.11 \pm 0.0260$, $0.896 \pm 0.129$ and $1.03 \pm 0.123$, respectively. MDR1 mRNA expression was significantly lower in EC109/CDDP cells as compared to EC109 cells $(\mathrm{P}<0.001)$; however, there was no difference in expression of MRP1, LRP, ABCG2 and GST-pi mRNA (Fig. 5B).

\section{Discussion}

Cisplatin resistance can occur at many levels, including changes in drug accumulation, intracellular thiol levels, DNA adduct repair and evasion of apoptosis (14). The establishment of drug-resistant cancer cell lines is crucial for understanding the biological characteristics of resistant cells, the mechanisms of drug resistance and overcoming it. There have been few studies on ESCC drug-resistant lines (15-17), which impedes the research on the mechanism of drug resistance of ESCC. Although Cui et al (16) reported a resistant cell line selected from EC109 cells as the same one that was used in this study, the resistance index of their cells to CDDP was only 1.56, and sensitivities to other drugs were not discussed. In this study, we established a drug-resistant ESCC line, EC109/ CDDP cells, by pulse treatment, which is similar to the clinical pulse protocol for ESCC patients. Furthermore, the relevance of EC109/CDDP cells to CDDP is high as CDDP is a primary chemotherapeutic agent for ESCC. 
A

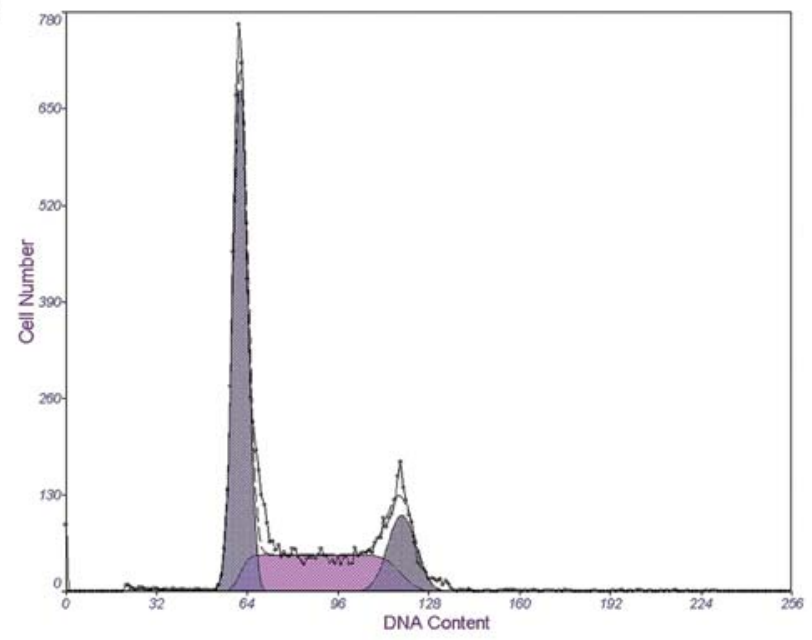

B

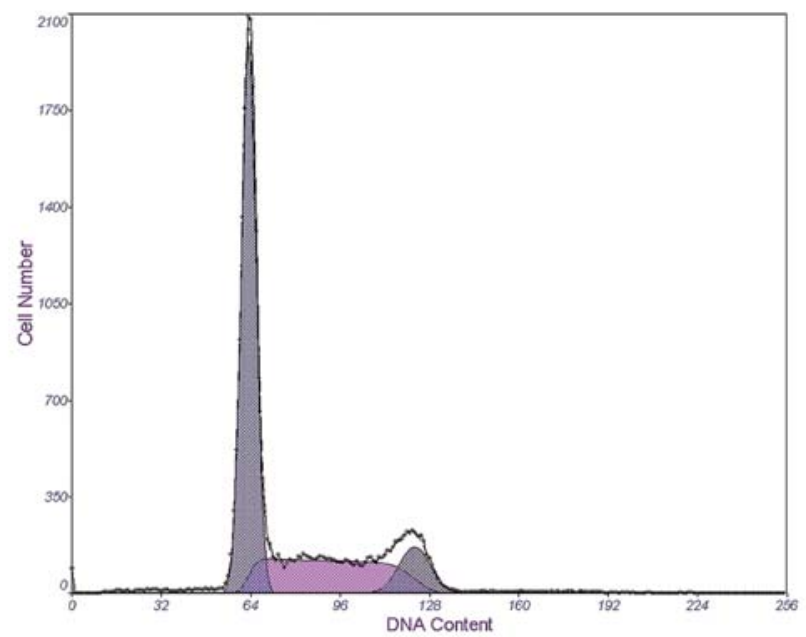

Figure 4. Cell cycle distribution of EC109 (A) and EC109/CDDP (B) cells.

A

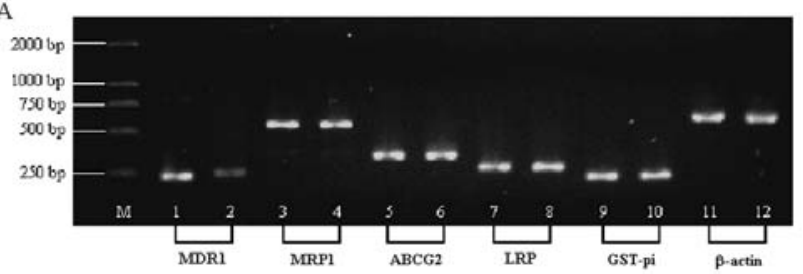

B

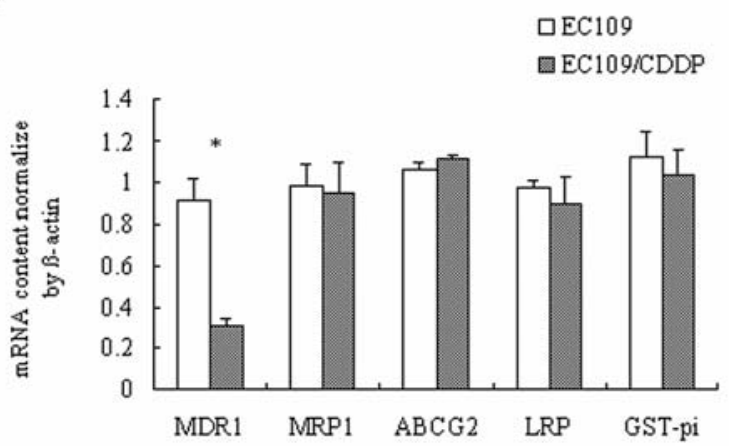

Figure 5. RT-PCR analysis of EC109 and EC109/CDDP cells. Agarose gel electrophoresis pattern of RT-PCR products for MDR1, MRP1, 1ABCG2, LRP, GST-pi and B-actin (A). Lane M, DNA marker; even lanes, EC109; odd lanes, EC109/CDDP; Lane 1-2, MDR1; Lane 3-4, MRP1; Lane 5-6, ABCG2; Lane 7-8, LRP; Lane 9-10, GST-pi; and Lane 11-12, B-actin. mRNA expression levels of MDR1, MRP1, ABCG2, LRP and GST-pi after normalized relatively to that of $B$-actin (B). ${ }^{*} \mathrm{P}<0.001$.

After 4 months of culturing in drug-free medium, decreased resistance of EC109/CDDP cells was not detected, indicating it is an appropriate model of ESCC drug resistance. As compared with the parental EC109 cells, EC109/CDDP cells showed 8.668-fold resistance to cisplatin, 5.568-fold to carboplatin and cross-resistance to other structurally and mechanistically different drugs, including an anti-metabolite, 5-FU, anti-microtubule agents, taxol and navelbine, and topoisomerase inhibitors, irinotecan and etoposide. This multidrug-resistant characteristic of EC109/CDDP cells might imply failure of chemotherapy combinations of cisplatin with 5-FU, taxol, navelbine, etc. in clinical practice.
Morphologically, EC109/CDDP cells showed some differences from EC109 cells in terms of cell shape, size and cytoplasmic vacuoles. After analyzing the ultrastructural morphololgy, Meijera et al (18) found an extensive Golgi apparatus and an increased number of mitochondria in the human small cell lung cancer cisplatin-resistant cell line, GLC4-CDDP cells, in contrast to its parental cell line, GLC $_{4}$. These changes might facilitate the cisplatin-resistant cell survival by increasing energy production/metabolism and further increasing DNA repair directly, or modulating the signal transduction pathways leading to cell death indirectly.

In this study, the resistant subline grew much slower than the parental cell line; specifically, the doubling time of EC109/CDDP cells was nearly twice that of EC109 cells (36.12 vs. $20.74 \mathrm{~h}$ ). This might be caused by the existence of non-cycling dormant cells. Furthermore, the percentage of EC109/CDDP cells in $\mathrm{G}_{0} / \mathrm{G}_{1}$ was higher and in $\mathrm{S}$ was lower than that of EC109 cells in corresponding phases. There is a critical balance between cell cycle arrest (promoting DNA repair and survival) and cell death following chemotherapy. In response to DNA damage, some genes will be activated or inactivated to induce cell cycle arrest in $\mathrm{G}_{1}$ phase in order to repair damaged DNA (19). In addition, it has been demonstrated that cells could stay in a transient state in which cells undergoing repair are survival-competent (20). A higher percentage of EC109/CDDP cells were in the $\mathrm{G}_{0} / \mathrm{G}_{1}$ phase, possibly indicating an enhanced capacity in DNA damage repair, which could be considered a mechanism of drug resistance.

Previous studies showed that increased drug efflux lowers intracellular drug concentration and contributes to multidrug resistance. This mechanism is caused mainly by ATP-binding cassette $(\mathrm{ABC})$ transporters, including MDR1, MRP1 and ABCG2 (21). Also, LRP could confer drug resistance by redistributing drugs away from intracellular targets (21). In addition, GST-pi, which is a member of a family of enzymes involved in xenobiotic detoxication reactions, takes part in the enzymatic inactivation of cisplatin so as to arouse the resistance phenotype (14). Therefore, we used semiquantitative RT-PCR to detect the expression level of these 
genes in EC109 and EC109/CDDP cells. Although there were no significant differences in MRP1, ABCG2, LRP, and GST-pi mRNA expression between EC109 and EC109/ CDDP cells, MDR1 expression was significantly decreased in EC109/CDDP cells compared with EC109 cells, which seemed to conflict with the role of the MDR1 gene product, P-gp, as a drug efflux pump (21). However, other studies have also found that some drug-resistant-related genes, including MDR1 and MRP1, did not increase in other resistant cancer cell lines $(5,22)$. It has also been shown that the increase observed in MDR1 mRNA did not parallel with an increase either in P-gp protein expression or activity (23). Therefore, $\mathrm{P}$-gp protein level and/or activity, but not MDR1 mRNA level, may determine drug resistance. On the other hand, drug resistance is a multi-factorial problem and there could be some other important mechanisms accounting for the drugresistant phenotype.

In summary, our study established the stable, EC109/ CDDP drug-resistant ESCC cell line, which showed crossresistance to several drugs of different structures and mechanisms. Thus, this cell line could serve as a useful tool for further study on the molecular mechanism(s) of ESCC drug resistance and might facilitate the discovery of potential therapeutic targets for ESCC.

\section{Acknowledgements}

The study was supported by Guangdong Natural Science Foundation (Grants No. 7001531).

\section{References}

1. Parkin DM, Bray FI and Devesa SS: Cancer burden in the year 2000. The global picture. Eur J Cancer 37: S4-S66, 2001.

2. Siewert JR and Ott K: Are squamous and adenocarcinomas of the esophagus the same disease? Semin Radiat Oncol 17: 38-44, 2007.

3. Stein HJ, Sendler A, Fink U and Siewert JR: Multidisciplinary approach to esophageal and gastric cancer. Surg Clin North Am 80: 659-682, 2000

4. Juliano RL and Ling V: A surface glycoprotein modulating drug permeability in Chinese hamster ovary cell mutants. Biochim Biophys Acta 455: 152-162, 1976.

5. Yan XD, Li M, Yuan Y, Mao N and Pan LY: Biological comparison of ovarian cancer resistant cell lines to cisplatin and taxol by two different administrations. Oncol Rep 17: 1163-1169, 2007.

6. Cole SP, Bhardwaj G, Gerlach JH, et al: Overexpression of a transporter gene in a multidrug-resistant human lung cancer cell line. Science 258: 1650-1654, 1992.
7. Scheper RJ, Broxterman HJ, Scheffer GL, et al: Overexpression of a M(r) 110,000 vesicular protein in non-P-glycoproteinmediated multidrug resistance. Cancer Res 53: 1475-1479, 1993.

8. Doyle LA, Yang W, Abruzzo LV, Krogmann T, Gao Y, Rishi AK and Ross DD: A multidrug resistance transporter from human MCF-7 breast cancer cells. Proc Natl Acad Sci USA 95: $15665-15670,1998$

9. Gutmann H, Fricker G, Torok M, Michael S, Beglinger C and Drewe J: Evidence for different ABC-transporters in Caco-2 cells modulating drug uptake. Pharm Res 16: 402-407, 1999.

10. Grant CE, Kurz EU, Cole SP and Deeley RG: Analysis of the intron-exon organization of the human multidrug-resistance protein gene (MRP) and alternative splicing of its mRNA. Genomics 45: 368-378, 1997.

11. Deichmann M, Thome M, Egner U, Hartschuh W and Kurzen $\mathrm{H}$ : The chemoresistance gene ABCG2 (MXR/BCRP1/ABCP1) is not expressed in melanomas but in single neuroendocrine carcinomas of the skin. J Cutan Pathol 32: 467-473, 2005.

12. Baron JM, Holler D, Schiffer R, Frankenberg S, Neis M, Merk HF and Jugert FK: Expression of multiple cytochrome p450 enzymes and multidrug resistance-associated transport proteins in human skin keratinocytes. J Invest Dermatol 116: 541-548, 2001

13. Kuzma M, Jamrozik Z and Baranczyk-Kuzma A: Activity and expression of glutathione S-transferase pi in patients with amyotrophic lateral sclerosis. Clin Chim Acta 364: 217-221, 2006.

14. Siddik ZH: Cisplatin: Mode of cytotoxic action and molecular basis of resistance. Oncogene 22: 7265-7279, 2003.

15. Toshimitsu H, Hashimoto K, Tangoku A, et al: Molecular signature linked to acquired resistance to cisplatin in esophageal cancer cells. Cancer Lett 211: 69-78, 2004.

16. Cui HJ, Jin G, Yang HY, Huang YT, Zheng ZM, Zhao JM and Dong ZM: Expression of DNA polymerase $\beta$ in a cisplatininduced human esophageal cancer drug-resistant cell line. J Zhengzhou University (Medical Sciences) 40: 17-19, 2005.

17. Li M, Wang ZJ, Fu Q, Zhao GQ and Dong ZM: Establishment of a cisplatin-induced human esophageal carcinoma a drug resistant cell line and screening of drug resistance-related genes. Chin J Health Lab Tech 17: 18-20, 2007.

18. Meijera C, van Luyn MJ, Nienhuis EF, Blom N, Mulder NH and de Vries EG: Ultrastructural morphology and localisation of cisplatin-induced platinum-DNA adducts in a cisplatin-sensitive and -resistant human small cell lung cancer cell line using electron microscopy. Biochem Pharmacol 61: 573-578, 2001.

19. Longley DB and Johnston PG: Molecular mechanisms of drug resistance. J Pathol 205: 275-292, 2005.

20. Ranganathan AC, Adam AP, Zhang L and Aguirre-Ghiso JA: Tumor cell dormancy induced by p38SAPK and ER-stress signaling: An adaptive advantage for metastatic cells? Cancer Biol Ther 5: 729-735, 2006.

21. Gottesman MM, Fojo T and Bates SE: Multidrug resistance in cancer: Role of ATP-dependent transporters. Nat Rev 2: 48-58, 2002.

22. Li L, Luan Y, Wang G, et al: Development and characterization of five cell models for chemoresistance studies of human ovarian carcinoma. Int J Mol Med 14: 257-264, 2004.

23. Gomez-Martinez A, Garcia-Morales P, Carrato A, et al: Posttranscriptional regulation of $\mathrm{P}$-glycoprotein expression in cancer cell lines. Mol Cancer Res 5: 641-653, 2007. 